\title{
Policy Implementation of Poverty Alleviation through Unfeasible House Improvement Reside Known as (RTLH) Program in Central Java Province
}

\author{
Pratisto Nugroho ${ }^{1}$, Kismartini ${ }^{2}$ \\ \{pratistonugroho@gmail.com ${ }^{1}$ \} \\ Universitas Diponegoro, Indonesia ${ }^{1,2}$
}

\begin{abstract}
Poverty is a phenomenon of human life, which generally depicts human inability to fulfill necessities; usually, poverty is synonymous with hunger, inability to control existing resources. Nationally the percentage rate of poverty in Central Java Province results in 2018 is still higher than the national achievement. The percentage of poverty in Central Java Province in 2018 was $11.32 \%$, while the national poverty percentage was $9.82 \%$. This research aims to analyze, identify supporting, and inhibiting factors of poverty alleviation policy through policy implementation of poverty alleviation through Unfeasible House Improvement Reside known as (RTLH) program. The theory used in this study was a theory stated by Grindle [1]. Where in the theory is stated that affecting the policy implementation there are two large variables, namely Content of Policy and Context of Implementation? The research method used in research is qualitative. By selection of informant is using purposive sampling and as a means of testing the validity of data is using triangulation. Preliminary research results show that being a supporting factor in this study is the contents of the policy governing RTLH in the regulation of the Minister of Social Number 20 in 2017 on social rehabilitation, home unfeasible and infrastructure facilities Environment. Meanwhile, the solution is the implementation of the policy environment that is in the middle of the current provincial community of Central Java.
\end{abstract}

Keywords: Unfeasible House; Content of Policy; Context of Implementation, and Purposive Sampling.

\section{Introduction}

The problem of poverty is one of the latent problems in the lives of human society. Poverty is a fact of social life depicting humanitarian conditions that do not conform to the humanitarian. Therefore, both individually, as well as in groups, humans are always to tackle, eradicate and reduce the amount of poverty in its society. Poverty relates to the low degree of health and nutrition indicated by people's ability to stay healthy, the ability to go to the doctor, low access to clean water and sanitation facilities. Poverty relates to the "powerlessness" situation that results in the inability or felicity of a person or group of people to protect them so that they are vulnerable to shock, violence, and criminality. Thus, poverty is a multidimensional, compound-faced phenomenon, transforming over time, moving around and explaining in a variety of ways. Poverty conditions in Central Java Province when based on data reported by the Central Statistical Agency known as BPS in 2018 percentage is still high 
compared to the national average. The percentage of poverty in Central Java Province in 2018 amounted to $11.32 \%$ while at the national level the percentage of its poverty was $9.32 \%$.

In addition, the condition of poverty that occurs in Central Java Province is much happening in rural areas than people in urban areas, with a percentage of $12.99 \%$ and a population of 2,181.04 million lives. While the percentage of poverty in urban areas in Central Java Province currently $9.73 \%$ with a population of $1,716.16$ million, which seen in Figure 1 below. The number of poverties that occurred in rural areas in Central Java Province, now the government began to implement a program to overcome poverty by assisting people whose homes are not habitable to be habitable. By fixing a house that was initially unworthy to be habitable, the basic needs of education and environmental health fulfilled. Where children able to learn comfortably, and their health in a clean environment maintained. Thus, it can reduce the burden on medical expenses due to illness caused by slum environmental factors.
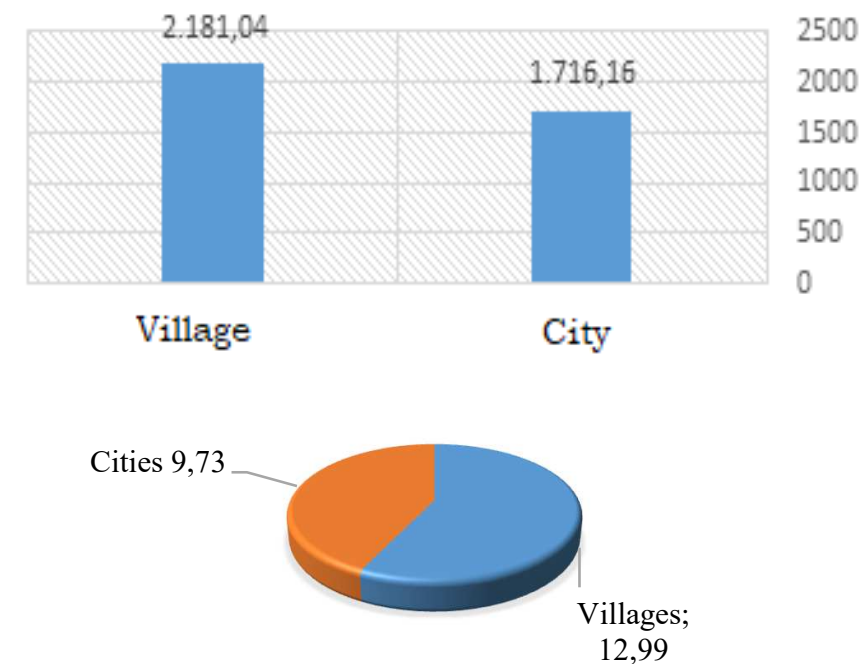

Fig. 1. Population and Percentage of Poverty-based on Residential Areas Source: Central Statistical Agency of Central Java, 2018.

The strategy of Unfeasible House Improvement Reside known as (RTLH) for the poverty communities is through this activity according to the Governor Regulation of Central Java. This Letter of GUB Number 460/0002907, about synergy program of poverty tackling on February 11, 2016, stated that this third party should take a handle commitment onto policy implementation of Division of the Handling authority of RTLH, clarifying as follows: $20 \%$ Central, 30\% Province, and 50\% Regency/City. Handling of habitable home in Central Java Province Nowadays still a lot to implement because based on the time of PBDT data in 2015 there is still $\pm 1,584,516$ RTLH that has not been resolved. The study of poverty reduction through the RTLH program based on the regulation of the Minister of Social of Indonesia Republic No. 20 in 2017 about social rehabilitation of home unfeasible and environmental facilities. This research aims to analyze and identify factors that encourage and inhibit poverty alleviation policy through the RTLH Program in Central Java Province in addressing problems 
related to the safety and health of the house residents. By Using the theory expressed by Grindle [1], in which the theory is mentioned there are two large variables that can affect the implementation of policies that are from the Content of Policy and Context of Implementation. Using the theory expected known that the supporting or inhabiting of whether the policy regulation related to the RTLH Program or implementation environment in the midst of the community in the District/City of Central Java Province today.

\section{Research Method}

This research uses qualitative research methods, where this method is a method of research contrary to experimental methods, this research method applied to examine the condition of natural objects and researchers have a duty and function as a key instrument in digging a major problem that would reveal in a research object that would implement [2].

The phenomenon that observed in this study is poverty reduction through the RTLH Program in Central Java Province. The focus seen from a public policy study perspective by looking at the analysis of the results and identifying the supporting factors and inhibiting poverty alleviation policy through the RTLH Program in Central Java Province. The object of this research is in the region of Central Java Province. The location of this research was chosen, based on existing data, which currently is Central Java Province, which includes the second-highest poverty level in Indonesia, although based on statistical data, it has been able to significant poverty but still remains on top of national achievement.

In this research, the informant taking the role of resources in observing data and taking an interview activity, in addition to documents that are supporting this research classified as policy implementers (stakeholders). It relates to the policy of the strategy of Unfeasible House Improvement Reside known as (RTLH) in Central Java Province, which consists of as follows. Head of Institution and Social Agency Staff, Agency for Regional Development abbreviated as BAPPEDA, Public Housing Office and Settlements of Central Java Province abbreviated as Disperakim Who is currently in charge of poverty, and people who benefit from the help of unfeasible dwelling places in some Districts/Cities in Central Java province.

In this study, apply methods of determining the informant by using the purposive technique, where the selection of the informant chosen based on the evaluation of the researcher that they were a party that many know about the problem of poverty reduction by using the current RTLH program [3]. The data collection techniques in this study conducted in the following ways: documentation studies, interviews, and observations. With the main Data collection instruments is the researcher itself with the help of a Tape Recorder tool to record, digital camera, stationery, and interview guidelines utilized by researchers at the time of searching for Data and facts when in the field.

In examining the validity levels of data in this research researcher applies triangulation techniques. Moleong [4] classified four kinds of triangulation as a technique for the use of source, method, investigator, and theory. The triangulation technique in this research using data source uses as examination technique execute by comparing data and checking well the degree of trust of information obtained through different time and way.

Miles, Haberman \& Saldana [5], suggested that activities in the analysis of qualitative data conducted interactively and continued continuously until complete so that the data was saturated. The data saturation measure that marked by no more data or new information. The activities in the analysis include data reduction, data presentation, and conclusion drawing 
(verification), as well as withdrawal of conclusions and verifications. Where the stage includes three threads of activity after the data collection process, namely: data condensation, data presentation, and withdrawal of conclusions. However, data analysis not done partially and independently but is done continuously and integrated during and after the data, the collection process is done in the research field.

\section{Result and Discussion}

\subsection{Content of Policy as a Supporting Factor of Policy Program of Unfeasible House Improvement Reside Known as (RTLH) in Central Java Province}

Based on the research results conducted by researchers at the time of the field, known that the current Variable content of policy is regulation of the Minister of Social of the Indonesia Republic Number 20 in 2017 about Social rehabilitation of house unfeasible and environmental infrastructure facilities are becoming a supporting factor in this research. Grindle [1] suggested that the indicator that affects the Content of Policy variable is the extent to which the target group's interests are contained in the policy content, the type of benefits received by the target groups. Wahab [6], stated extent of the desired change of a Policy, whether the location of a program is appropriate, whether a policy has mentioned its implementation in detail, and whether a program is supported by adequate resources it can be seen from some of the chapters in these Regulations.

Based on the research results that implemented noted that the symptoms/indicators that are the extent of the Community interest contained in the content of the policy seen in Chapter I in Article 1. Where in the article explained that as follows: 1. Invisible House hereinafter referred a dwelling place or usually called Rutilahu that does not fulfill health, safety, and social requirements. 2. Social rehabilitation of dwelling place (Rutilahu) is the process of restoring the social functioning of poor people through efforts to improve the condition of a dwelling place (Rutilahu) either partially or entirely done by mutual assistance to create a decent home condition as a dwelling place. 3. Environmental Infrastructure Facilities hereinafter called, as Starling is a public facility that built by mutual assistance to support the environment of residence or residence to improve the quality of life. 4. Poor is a person who has absolutely no source of livelihood and/or has a source of livelihood but does not have the ability to fulfill the necessities that deserve to their life and/their family. 5. Social assistance is assistance in the form of money, goods, or services to the poor or incapacitated people to protect the community from possible social risks, improve economic capabilities as well as community welfare [7].

The symptoms/indicators of the benefits and policy changes desired by the community are contained in article 2. In that article mentioned the social rehabilitation of dwelling place (Rutilahu) and Environmental Infrastructure Facilities (Starling) aims to restore social functioning and increase the quality of poor communities. This program executes through the improvement of the house condition as well as environmental infrastructure both in whole and in part by using the spirit of togetherness, Working Group known as (Gotong Royong), and the value of social solidarity society.

The symptoms/indicators included in the program's accuracy and the clear implementations of the poverty alleviation policy through the RTLH program listed in section 3.4, and 10. Where in article 3 mentioned that the revised Rutilahu criterion includes as 
follows. A. Walls and/or Roofs in damaged conditions that could harm the safety of the occupants; B. Walls and/or Roofs made of easily damaged/weathered materials; C. Floors are made of ground, plank, bamboo/cement, or ceramics in damaged conditions. D. it does not have bathing, washing, and feces pit; and/or E. Floor area less than $7.2 \mathrm{~m} 2 /$ person (seven commas two square meters per person). In article 4, which is the recipient of social assistance, dwelling place (Rutilahu) Social rehabilitation must be eligible as follows: a) Indigent family that is data in integrated data of the poor management program; b) Have not received the social assistance of dwelling place (Rutilahu) social rehabilitation; c) Have a self-identity cards or family card; d) have house on its own land that improved by the certificate/ Indemnity Letter (Girik) or the letter of ownership from the District-Head as District official. While clarity implementation of poverty alleviation policy through RTLH repair program found in article 10. In Article 10, mentioned that as follows:

The Application for social rehabilitation of dwelling place (Rutilahu) submitted by the homeowner, community, or social welfare institution as referred to in article 9 letter A and letter B done by mechanism steps as follows: a) Apply for social assistance dwelling place (Rutilahu) to the village head/another name; b) Head of village/other name conducting deliberation; c) Head of village/other name apply in proposal form to the social service of District/City; d) District/City Social service verify and validate the prospective beneficiary's social rehabilitation of dwelling place (Rutilahu) based on integrated data of the program handling of indigent family; e) The result of verification and validation conveyed by the social service of district/city to the Minister of Social through the Director-General of poor management with the copy conveyed to the head of provincial social service; f) Directorate General of Management of poor, verification and validation of prospective beneficiaries of dwelling place (Rutilahu) social rehabilitation on proposal of social service in District/city; g) Director general of poor management set the location and recipient social assistance social rehabilitation of dwelling place (Rutilahu); h) The determination of the location and recipient social assistance of social rehabilitation submitted to the social service of the district/city with a copy conveyed to the social service of the Provincial district; i) Head of District/City social service delivered the results of the location to the recipient social assistance of Rutilahu; $\mathrm{j}$ ) District/city Social services sign a letter of absolute responsibility with the stamp enough on the truth of the terms and criterion of the recipient social assistance of Rutilahu.

The symptoms/indicators that contain the resources of the non-human field contained in articles 17 and 18 articles 17 mentioned that: (1) Social assistance Social rehabilitation of Rutilahu at least IDR.15.000.000 Million in a house. (2) Social assistance Environmental Infrastructure Facilities (Starling) is at least IDR.50.000.000, 00 (fifty million rupiahs) per location. In addition, continued in article 18 is written as follows: (1) social assistance of social rehabilitation dwelling place (Rutilahu) and Environmental Infrastructure Facilities (Starling) as referred to in article 17 paragraph (1) and paragraph (2) in the form of building materials and building equipment. (2) Building materials and building equipment as referred to in paragraph (1) shall be contained in the appendix, which is an integral part of this ministerial regulation. There is conformity between the theory used by researchers with the contents of the policy in the Social Minister Regulation of Indonesia Republic Number 20 in 2017 about social rehabilitation of unfeasible house and environmental infrastructures show that between Articles one with the article in the Ministerial Regulation does not overlap among one another. 


\subsection{Context of Implementation as an Inhibitor Factor of Program Policy on Poverty Reduction through Unfeasible House Improvement Reside known as (RTLH) in Central Java Province}

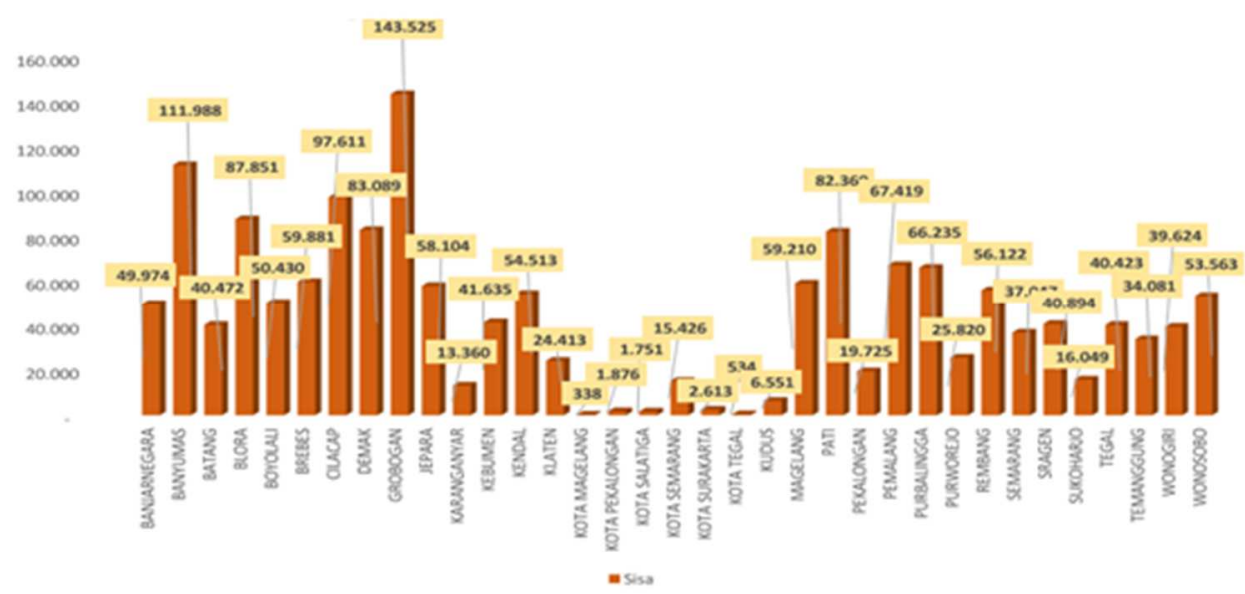

Fig. 2. The Amount of Unresolved RTLH in Central Java Province

Note: The Remnant of Higher Education Database known as PDPT in 2015 (Starting from 2018). Source: Statistical Centre Agency of Central Java Province, 2018.

Based on the research results conducted by researchers at the time of the field, it is possible to observe that this currently variable OF implementation environment (Context of Implementation) to be an inhibitory factor in this research. Howlett, Perl \& Ramesh [8] suggested that the indicator that affects the variable Context Of Implementation is to include how much power, interest, and strategy the actors have involved, the characteristics of the institution and the regime that is being Compliance and responsiveness of target groups.

The number amount of Unfeasible House Improvement Reside known as (RTLH) that have not been repaired, according to the informant of the community that was successfully encountered by researchers at time in field because currently, the nominal number of rehabilitation assistance given home is not as contained in Regulation of t Minister of Social Number 20 in 2017. It started about the social rehabilitation of home unfeasible and environmental infrastructure facilities. The provincial government of Central Java at this time was only able to provide substantial assistance IDR. 10 million, - whereas in the Regulation of Ministry of Social is written the aid of the rehabilitation house is not habitable is IDR.15 million-. In addition, because of its self-reliance, the development of home improvement is only relying on the workforce of Community volunteers; therefore, it requires or takes a long time. The small amount given by the provincial government of Central Java in providing assistance to repair RTLH for the poor is not responded properly; due to the basic spending needs to improve, their home is larger than the aid provided by the current government. In addition, many communities refuse to improve their homes, despite the verification and validation of data carried out the rehabilitation for their unfeasible house today.

The absence of conformity between the theories applied, the regulation of the policy that applied, with the implementation in that field so that the program to repair RTLH for the poverty community in Central Java Province there are still a lot of problems happening. Being a factor of poverty alleviation policy because at this time the magnitude of power, interests, 
and government strategy in implementing the Poverty Reduction program through the improvement of RTLH is not properly formulated resulting in the remaining amount of Integrated Database Updates known as PBDT in 2015 (Per 2018). In every Regency/City in Central Java, there are still many unhandled, because of the lack of a good response from the poverty community, especially in 14 districts/cities in red area (priority area) based on Integrated Database such as the districts of Wonosobo, Kebumen, Brebes, Pemalang, Purbalingga, Banjarnegara, Rembang, Banyumas, Sragen, Klaten, Demak, Grobogan, Blora, and Purworejo.

\section{Conclusion}

The results of this research become a real representation that the poverty alleviation policy through the Poverty Reduction through Unfeasible House Improvement Reside known as RTLH Improvement Program conducted in Central Java Province has not been successfully carrying out. So that the objectives to be achieved in Regulation of the Minister of Social Number 20 in 2017 about social rehabilitation of unfeasible house and environmental facilities infrastructure cannot be materialized in the midst of society. Where it characterized by still many problems related to the Poverty Reduction through Unfeasible House Improvement Reside known as an RTLH repair program that is in the form of rehabilitation assistance that has not been in accordance with its policy regulation. And if the accepted then it can be ensured the beneficiaries are forced to add their own money because they received not enough, as well as the time it takes to build a habitable home relatively in a long period, because currently, its nature relies solely More on mutual assistance in every village.

Contributing factors to poverty alleviation policy are through the Unfeasible House Improvement Reside Program, the Minister of Social Law Number 20 in 2017 on social rehabilitation of unfeasible dwelling place and environmental facilities. This regulation is a supporter of policy because the articles in the policy regulation have been set in full, from the objectives, benefits, implementation, to the cost of rehabilitation of home improvement is not feasible contained in this regulation.

The prevention of poverty reduction policy through the Unfeasible House Improvement Reside Program is its policy implementation environment. This is because the magnitude of the power, interests, and strategies owned by the leader or the stakeholder's capacity policy is not maximized, causing the response given by the public in implementing the RTLH repair program to reduce the level of poverty in Central Java Province is still not successful. Therefore, the recommendation provided by researchers is an improvement in the field of institutional by finding a leader who has a creative and innovative thinking capacity that complies with the prevailing rules. With the expectation of a response given to the community especially for beneficiaries of home improvement, programs are not habitable to be better than in previous years.

\section{References}

[1] M. S. Grindle, “Good Enough Governance,” Dev. Policy Rev., 2011.

[2] Sugiyono, "Metode Penelitian Kuantitatif, Kualitatif dan R\&D," Alf. Bandung, 2014.

[3] K. I. . et. al Al-Sulaiti, "Research Methods for Business Students," Int. Mark. Rev., 2010.

[4] L. J. Moleong, "Metodologi Penelitian Kualitatif (Edisi Revisi)," in PT. Remaja Rosda Karya, 
2017.

[5] M. B.Miles, A. M. Huberman, and J. Saldana, Qualitative Data Analysis - Matthew B. Miles, A. Michael Huberman, Johnny Saldaña - Google Books. 2014.

[6] S. A. Wahab, Analisis Kebijaksanaan: Dari Formulasi ke Implementasi Kebijaksanaan Negara. Jakarta: PT. Bumi Aksara, 2004.

[7] O. F. S. Kawer, M. Baiquni, Y. T. Keban, and A. Subarsono, "Implementasi Kebijakan Pembangunan Rumah Layak Huni Dengan Pendekatan Hibrida Di Kabupaten Supiori Provinsi Papua," Sosiohumaniora, 2018.

[8] M. Howlett, M., Perl, A., \& Ramesh, "Policy Formulation: Policy Instruments and Policy Design Policy," in Studying Public Policy: Policy Cycles and Policy Subsystems, 2009. 